\title{
Disciplinization of Gender Studies. Old Questions, New Answers? \\ Nordic Strategies in the European Context
}

Published in NORA: Nordic Journal of Women's Studies 2006; 14 (2):131-140

Karin Widerberg, University of Oslo karin.widerberg@sosgeo.uio.no

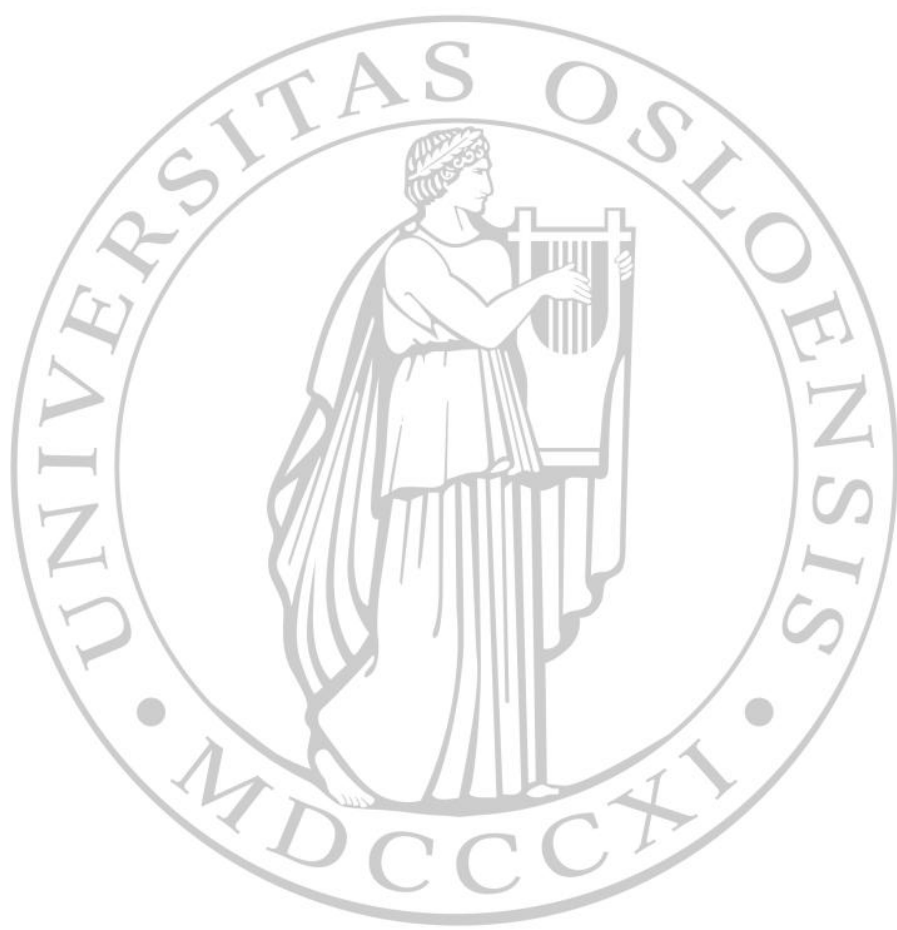

Department of Sociology and Human Geography University of Oslo

P.O.Box 1096 Blindern

N-0317 OSLO Norway

Telephone: $\quad+4722855257$

Fax: $\quad+4722855253$

Internet: http://www.iss.uio.no 


\title{
Disciplinization of Gender Studies. Old Questions, New Answers? Nordic Strategies in the European Context.
}

\author{
Karin Widerberg
}

Author presentation.

Karin Widerberg Ph.D., Professor of Sociology at the Department of Sociology and Human Geography, University of Oslo.

Widerberg has published books and articles on feminist theory of science and methodology, understandings of gender, sexual violence and law from a feminist perspective. Her recent publications include Oppgaveskriving (Universitetsforlaget 2004, in Swedish Studentlitteratur 2003), Historien om et kvalitativt forskningsprosjekt (Universitetsforlaget 2001, in Swedish Studentlitteratur 2002) and Trøtthetens tid (co-authored with Ulla- Britt Lilleaas, Pax 2001).

\begin{abstract}
The old question if - and then how - to make a discipline out of Women's Studies is raised anew in Europe in 2005/6 as a result of the restructuring of the higher education system brought about by the Bologna agreement. Based on material from an on-going EU-project on interdisciplinarity between the social sciences and humanities, this article argues that in the long run institutionalization and disciplinization actually go hand in hand with the integration of the subject in the traditional disciplines. They presuppose and even promote each other rather than undermine or exclude one another. Here focusing on the situation in Sweden, Norway and Finland, the situation in UK and France are used as comparative illustrations. As part of the background of a more general description of the development of Gender Studies in these countries, a recent example of disciplinization - the Bachelor Degree in Gender Studies at the University of Oslo - is also presented and discussed.
\end{abstract}


In Western Europe Women's Studies was initiated as the academic response to the women's movements and the gender equality ideology of the 1970s. The lack of female professors and of gender perspectives in teaching, curricula and research called for support and collaboration across disciplinary boundaries. It was argued that 'gender' did not 'belong' to any discipline in particular and that disciplinary barriers as such might hinder the development of understandings of gender. A need for new approaches and methods, for an interdisciplinary approach, was articulated. However, there were - and still are - quite different views both within the countries as well as between them as to if and how Women's Studies should be institutionalized. Should the aim be "intregration/mainstreaming (criticized as assimilation and "malestreaming") or separation (criticized for ghettoization) within academia, or should it be feminist knowledge organizing outside academia for the "average woman"?

Today, these views may have changed as a result of the experiences with the strategy chosen, as well as as a result of new knowledge paradigms and/or a different structural situation including new generations of students and researchers (see for example Griffin 2002 and the special issues of Feminist Studies no 2 (2001) and Differences no 3(1997) dealing explicitly with these issues and questions). The aim of this article is to raise these questions about integration and disciplinization ${ }^{\mathrm{i}}$ anew and to offer some perspectives and reflections that can inform the debate about disciplinization of Gender Studies ${ }^{\mathrm{ii}}$, reawakened by the Bologna process.

Based on the material produced through the EU-project 'Changing Knowledge and Disciplinary Boundaries Through Integrative Research Methods in the Social Sciences and Humanities' (www.hull.ac.uk/researchintegration) I will here focus on the situation in three Nordic countries: Norway, Sweden and Finland. Material about the situation in the UK and France will be used as a comparative illustration in an effort to answer the following question: Are there certain ways to go about particular types of actions - that seem more fruitful, in the long term, if and when aiming for disciplinization?

\section{Big countries, big sisters?}

What can the development of Women's Studies in big, old and powerful European countries like the UK and France teach us Nordic feminists?

Women's ownership of Women's Studies and the demand for courses by students were important factors for its disciplinization in the UK (the material of this section is primarily based on Griffin et al 2005: 29-39). In the 1970s and 1980s short, mainly optional courses were introduced that then met the education reform of modularization which paved the way for the emergence of full Women's Studies degree courses.

The first half of the 1990s was the heyday of Women's Studies in the UK, and it faced rapid change from offering modules within other courses only to independent Women's Studies courses. The number of Women's Studies degrees rose dramatically. The first Women's Studies degrees were all at postgraduate level but since these Masters degrees succeeded in attracting students, new undergraduate degrees were also established. However, in the last part of the 1990s the numbers of Masters students and undergraduates declined. As a result of the heavy focus on "marketability"- that is, the ability to "sell" and to attract "customers" (students) fewer courses were offered. 
In 2005 Women's Studies is still not recognized as an independent discipline within the funding bodies and the student numbers continue to decline. Some courses have closed down. However, more students than ever are taking modules with Women's Studies content within traditional disciplines. And feminist research is flourishing and encouraged if performed within traditional disciplines.

Summing up: In a comparative perspective marketability and a modular system of Higher Education initially favoured the development of courses and degrees in Women's Studies in the UK. At research level such components have less influence and even though specialization in Women's Studies is possible, it is still not (fully) recognized as a discipline at the level of research funding and assessment, that is, by some of the major gatekeepers of disciplinization.

The picture of Women's Studies in France is quite different (the material of this section is primarily based on Le Feuvre and Metso, 2005: 36-41). The radical nature of the women's movement of the 1970s made it hard for Women's Studies to fit into the structures of the centralized higher education institutions in France. There was skepticism both ways. Feminist academics were in a way betrayed by both parties - seen as militant and unscientific by the university systems and accused by the women's movement of letting them down and not being true to the values of the movement. Just like elsewhere Women's Studies started out as informal feminist groups at the universities fighting to introduce the topic into their own disciplines. However, unlike for example the UK, there was a lack of institutional support throughout. The institutionalization of Gender Studies did not take the form of a process towards an independent discipline, but was acted out inside traditional disciplines. This integration strategy was the only possible choice due to the strictly disciplinary structure of the French Higher Education system. It was also and equally importantly a function of France's constitutionally enshrined equality discourse which makes special pleading for any particular group or positive action an impossibility since all citizens are meant to be equal. In the 1990s there were only five senior lectureships with the specilization on Gender Studies in the whole country, all of them located in traditional disciplines. Today there are still only a handful of such positions and still no full professorships in Gender Studies. This of course raised problems regarding the supervision of $\mathrm{PhD}$ students interested in the subject. Some of the senior lecturers, despite strong international recognition, are still not recognized by the small minority of influential academic gatekeepers. Feminist researchers are seen as "militant" or "unscientific" and accordingly not promoted.

On the whole the development of the Gender Studies courses has been slow in France and only a few universities have managed to build up Women's Studies research centres. French Gender Studies has ended up in a vicious circle: because of the lack of institutional support for gender research there are very few lecturers and professors able to specialize in Gender Studies. Accordingly the capacity for lobbying for developing and establishing new courses and degrees is weakened. As a result few students are introduced to gender issues which means that few students specialize in Gender Studies and even fewer go onto PhDs in the subject.

Summing up: One striking feature in a comparative perspective is the international recognition of French feminist theory. Its interdisciplinary appeal and theoretical sophistication have intrigued and inspired gender researchers and students worldwide, and led to many courses in other countries on French feminisms. In these days of internationalization and competition, it is therefore hard to understand the lack of national recognition and support. The centralized and hierarchical male dominated structures of French academe are one major obstacle for the national recognition of 
gender research, the other is the equality discourse. The fact that academia, traditionally, is supposedly independent in relation to politics and societal concerns to a degree quite different from, for example, the Nordic countries, also diminishes the chances for political pressures for change. Gender equality politics, in other words, is not a force to count on for changes within academe. The need to fit in and be a part of what counts internationally has not been a necessary condition for the survival of French national education and research within the Social Sciences and Humanities - at least not until now. European collaboration - of which the Bologna agreement is an offspring - is a new challenge to this situation politically initiated from above. For small countries such as Norway, Sweden and Finland the situation is quite different. Here international comparison and recognition are now viewed as "the only way out".

\section{Small is beautiful?}

Already in the 1960s 'sex roles' research was recognized as a field of research within all the Nordic countries, headed by distinguished researchers, both males and females (Widerberg 2000, 471). In Sweden and Norway these perspectives were, however, challenged by the 'new' women's movement of the late 1960s and early 1970s. But a platform was there as well as some established gender researchers, which helped to facilitate the institutionalization process. In both countries women's research and teaching was organized hand in hand with the aim to increase the number of women in research. But the institutionalization process of Women's Studies took different paths in Sweden and Norway.

In Sweden, in response to feminist pressure, the government funded some undergraduate courses in Women's Studies in 1975, however, insisting on calling the subject 'equal opportunities research' (the material in this section is primarily based on Holm and Liinason 2005: 24-6, 31). The first Centre for Women's Research and Women Researchers (the name illustrating the double aim) was established in Lund in 1978 but soon after centres were established at most universities in the country. There, as elsewhere, it started out as a grassroots movement, in the form of a voluntary organization that only gradually got institutionalized as a permanent university unit with allocated space and economic support. A network and collaboration between the centres was organized already in the 1970s facilitating the institutionalization process. The state-funded centres became a significant feature of Swedish Gender Studies, and one of the major forces in the institutionalization of the subject. As an interdisciplinary meeting arena, the centres took the initiative to develop courses in Women's Studies that were offered both there and within traditional disciplines. The modular structure of Swedish higher education, already adopted in the 1970s, represented an invitation to develop short courses in the subject. As collaborative enterprises they did not demand many resources and were therefore welcomed by all parties. The centres in Sweden accordingly focused on teaching tasks while they were less organized and developed as research units or milieus.

Today it is primarily at the centres that education in Gender Studies is offered. This activity has increased over the years and today most centres even offer a full undergraduate degree in Gender Studies. Where such centres are absent Gender Studies is offered within the regular university structure. On the whole, the impression is that quite a substantial number of Gender Studies courses are offered throughout the Swedish higher education system (for an overview see hhtp://www.genus.gu.se/kurskatalog). But even though Sweden might be at the 
forefront regarding education in Gender Studies the proportion of female professors has been just as low there as in most other Nordic countries. At the end of the 1980s Sweden still had less than 10 percent female full professors. This resulted in the socalled Tham Initiative. The Tham prefessorships were named after Carl Tham, who was a Minister od Education in Sweden in 1995, when the Government and Parliament decided to establish a number of professorships (31) earmerked for women. Out of these thirtyone, nine were earmarked for discipline-oriented Gender Studies. This initiative - albeit much debated and discussed (Jordansson 2005, Törnqvist 2006) - gave Gender Studies a further institutional anchorage. And, importantly, it expanded the possibilities for $\mathrm{PhD}$ training and supervision in the subject in the disciplines. At the research funding level, the initiatives to grant the subject a proper place, have been fewer and less successful except for the Centres of Excellence, presented in the article by Keskinen \&Silius in this veryissue of NORA. This has been in sharp contrast to Norway, where the National Research Council has been the most important supporter of Women's Studies.

In Norway, due to the absence of a modular structure in higher education, Women's Studies was developed and offered as optional and extra courses or as perspectives within the disciplines from the 1970s and onward. Since the structure of education left few openings for the disciplinization of Women's Studies, focusing on research seemed one way to proceed. And so one did, and with great success. From the feminist research milieus developed within the disciplines, initiatives were taken in relation to the National Research Council, to facilitate the further development of Women's Studies, interdisciplinary collaboration and research activities (the material in this section is primarily based on Widerberg et al 2005: 35-8). In 1977 the Secretariat for Women's Research was established and located at the National Research Council. This Secretariat was unique not only in the Nordic context, but in Europe as a whole. It had three major tasks: a) to increase recruitment of women to research, b) to initiate and promote women' s research, and finally, c) to disseminate women' s research. This implied internal oppositional and underground work within the Council as well as external work in relation to research environments, universities, and society in general. The interdisciplinary Secretariat accordingly had the double task of pursuing both policy-oriented gender equality work and research, just like the local Women's Research centres in Sweden. The first task was fulfilled by investigating and pushing for gender quotas regarding grants, positions etc. and gathering women in science to inform and support them, for example in relation to research funding. The second task, the task to promote and coordinate women's research, was fulfilled through several and quite substantial research programmes on gender issues which single out Norway in the Nordic context. The Secretariat also supported or established networks and organized interdisciplinary and national research conferences on different topics relevant to women's research. Once the different centres were established, in the 1990s, the Secretariat also organized annual meetings to discuss the division of labour between these two sets of institutions. The Secretariat was the driving force behind various book series, research-political investigations and journals, which all fulfilled the task to disseminate women's research. The tremendously well-functioning Secretariat and the political goodwill that surrounded it most likely delayed the establishment of centres in Norway. The Secretariat also made it possible for the centres to concentrate on women's research and leave the task of increasing the number of women in (science) research with the Secretariat, a task that most other centres in the Nordic countries at least in the beginning had on their agenda. 
In Finland, the development of Women's Studies had a later start because the feminist movement started to grow relatively late (at the end of the 1970s) and never gained as strong a foothold as in the other Nordic countries (the material of this section is primarily based on Keskinen and Silius 2005: 22-8). As a consequence, teaching and research in Women's Studies was also established later. During the 1980s it started to become a field of teaching and research, and cooperation and networking between Women's Studies researchers started to expand. The funding authorities and equal opportunity policy-making bodies encouraged this development, and funding was provided for a national co-ordinator. The support of the Research Council and the Council for Equality was very important for promoting the subject, since it was not yet institutionalized in the universities. In the 1990s the activity grew and better resources were offered. During this period Women's Studies became an independent subject at several universities, while integrated in traditional disciplines in others. Eight five-year full professorships in Women's Studies funded by the Ministry of Education and one by the Research Council, were also established with the intention that the universities should take over the economic responsibility for these positions afterwards. Today Women's Studies is offered at basic, intermediate, advanced and $\mathrm{PhD}$ levels and the situation as well as its development resembles that of Sweden.

On a Nordic level collaboration within Gender Studies - buidling on a long tradition of co-operation between the Nordic Women's Organizations (Rosenbeck 1998, 346) - has been significant since the beginning of the 1970s (Holm and Liinason 2005: 25). It started out small with a Nordic study circle in the 1970s, institutionalized as the Nordic Summer University. Since then a number of Nordic networks" has unfolded within individual subjects, disicplinary fields and interdisciplinary studies alike (Rosenbeck 1998, 352). In 1992 The Nordic Journal of Women's Studies (NORA) was established, in 1995 NIKK- Nordic Institute for Women's Studies and Gender Research was founded and in 2004 a new network; The Nordic Thematic Network on the History of Women's and Gender Studies (TÓFA) was established and a Nordic Research School of Interdisciplinary Gender Studies introduced, just to mention a few but important issues of Nordic collaboration within Gender Studies. The possibility of applying for grants from a number of trans-Nordic research funding agencies under the auspices of the Nordic Council of Ministers, such for example The Nordic Academy for Advanced Study (initially NorFa now NordForsk) has sustained these collaborative initiatives. Moreover, Research Councils in the Nordic countries have included collaborative bodies, which have funded transNordic research projects.

Summing up: Characteristic for the Nordic countries is political support and support from the research funding bodies. Although universities have been just as slow as in most other western European countries in granting women researchers and feminist researchers full professorships, initiatives and money have come from the outside, from the public sector. The smaller the country, the closer are also the connections between researchers and politicians. In Norway quite a few feminist students and researchers of the 1970s and 1980s today hold strategic positions both within the Ministry of Education, the National Research Council and the Government. In Sweden, a country twice the size of Norway, these connections are not as close, direct or outspoken. But here gender equality politics presents a constant force attacking the walls of academia. Focusing on Women's Studies as teaching activity or as a research activity seems to be more the result of the higher education structures of the respective country than a result of strategic decisions. Finally, it is obvious that 
Women's Studies in the Nordic countries benefits from intra-Nordic comparisons, competitions and collaborations. What one country achieves, the others can also demand.

When discussing the disciplinization and institutionalization of Women's Studies the role of the centres is also central. Have they been a platform to further this process, or not? And what is the relationship between developing Women's Studies as a centre and developing Women's Studies within the disciplines? Do they strengthen or undermine each other?

A combination of teaching and research characterize the vast amount of Centres of Women's and Gender Research - around 30 all in all - that exist today in the Nordic countries. Most of these centres have increased their teaching as well as their research activities during their period of existence and gained more positions and resources and generaly been highly praised and evaluated both inside and outside academia. Their institutionalization do not seem to have been regarded as hampering the integration of the subject within the disciplines. I would in fact argue that it can be made to work the other way around, as the case of the BA at the Centre in Oslo (an example of a succesful strategy), described below, is meant to illustrate. However, the debate about integration or disciplinization has continued all along. In the 1980s and 1990s the positions were more outspoken and clear, while the development over the last couple of years seems more pragmatically oriented. Without much debate disciplinization and integration now seem to be done as parallel processes. So far institutionalization has generated resources for both research and teaching in the subject from which the other disciplines have also benefited. And the restructuring of higher education, as a result of the Bologna process, represents a chance to further institutionalization and disciplinization of the subject, which the centres seem to have been quick to grasp.

\section{A Degree of One's Own. The case of a BA degree in Gender Studies-disciplinization and integration.}

In 2003 a new interdisciplinary Bachelor programme titled 'Gender, Feminism and Equality' was offered at the Centre for Women's Studies and Gender Research at the University of Oslo (the material of this section is primarily based on Widerberg et al 2005: 32-5). Two aims were clearly expressed from the very start. The programme was to have both a political/practical and a theoretical/research agenda, it was in other words meant to be directed both towards those who wanted to work more practically with gender equality issues and those who wanted to develop a gender perspective more generally (including those planning to do research). With this aim in mind they developed a 'two-track' model in which the student after some introductory courses could choose the subject area Gender Equality or the area Gender Studies with Subject Specialization. The second aim was that the programme was not to be a deadend in relation to the disciplines. It had to be possible for the students to proceed to Masters studies; the disciplines were not to be able to lock them out. But since most Masters degrees require a certain amount of points or specific courses in the discipline they focus on, these requirements had to be built into the Bachelor programme offered by the Centre. Having a focus on Gender Perspectives, the Centre could not open up their programme to all kinds of disciplinary courses without such perspectives. The Centre accordingly approached all the disciplines that their future students were likely to proceed to Masters studies in, to see what they had to offer. Indirectly this made 
disciplinary gender perspectives and courses visible, and constituted a pressure to keep it all up and/or develop it. In the disciplines where such courses were lacking, the centre could offer their own courses or courses offered by other disciplines, but the discipline in question had to approve these in relation to the 80 points demanded (out of the 180 points which make up a Bachelor degree) for entry into disciplinary Master studies. On the basis of such negotiations contracts with 16 disciplines were outlined, making it possible for students to proceed to Masters level in the discipline they had chosen to major in within the Centre's Bachelor programme. For those choosing the Gender Equality track and lacking the prerequisite 80 points in disciplinary courses, there is so far only one Masters programme in Norway to which they formally have access and that is the one offered by the Department of Interdisciplinary Culture Studies at The Norwegian University of Science and Technology (NTNU) in Trondheim. However, it is quite possible also for students taking this track to plan their choice of courses so as to be able to enter a specific Masters programme.

Summing up, the model accordingly consisted of mandatory, introductory and interdisciplinary courses on gender and gender perspectives (first year), and two paths for the second and third year; one focusing on gender equality and the other focusing on a particular discipline where courses offered by the discipline in question are taken. Since the students have a great deal of freedom of choice in the second and third year, students from the two tracks might very well end up taking the same courses. It should also be noted that due to the reform of higher education the disciplines themselves are now able to offer more interdisciplinary courses and give credits to courses from other disciplines. Choosing Gender Studies with Subject Specialization did accordingly not mean a restriction to a discipline in any narrow sense. Quite the opposite. There were plenty of courses to choose from, including of a more interdisciplinary kind.

Such a model - impressive in its logistics and for its efforts to combine gender perspectives and disciplinary foundations, theory and praxis, could not be accused of ghettoization, quite the opposite. It would instead contribute to the strengthening of gender perspectives within the disciplines. And it was society oriented, offering a focus on practice (gender equality) as well as a research focus. The design of the model undermined any serious criticism and resistance, and no such criticism was in fact articulated. If the model had been less disciplinary and/or less practise-oriented and the contextual situation less favourable, the outcome might have been different.

\section{Concluding Remarks}

Across western Europe Women's Studies has had a similar start. The women's movement ignited an interest which, transformed into academia, resulted in short-term courses within most disciplines in the humanities and social sciences. As specialized courses, gender perspectives were integrated into the disciplines. The next step was to develop either a PhD training, Masters degree or specialization in the subject, or an undergraduate/Bachelor degree.The reasons for the strategy chosen have been practical (one was - before Bologna - not allowed to offer undergraduate credit bearing courses (Norway) or offer a Phd training or degree (Sweden) as well as ideological (a disciplinary undergraduate education might be considered to be necessary before specialization). Strategically, and in the long run going for the graduate level might however prove to be wise tactics. Scarce resources are hereby 
channeled into the more academically prestigious level at the same time as research competence is built up which in its turn can be used to further Gender Studies issues in both research and teaching. In most European countries there seems to have been a dual strategy, going both for integration and disciplinization. But the reasons for this and the alliance partners have changed over the past three decades. While the force was once with the women's movement, it now seems to be with the new theoretical and political paradigms (post-structuralism, queer, post-colonial etc). Here gender is made a theoretical issue attracting the interest of younger-generation students and researchers. With this as a platform there is a new push for interdisciplinarity. Centres are then the natural meeting ground for developing both research and teaching along these lines and it is also here that we find that these new perspectives flourish. Coming from within academe, theoretically sophisticated and still quite challenging, this might be a more successful road to disciplinization than the outside political alliance partner of the women's movement - at least today.

Summing up, the answer to the question raised in the introduction - whether there are certain ways to go about that are more fruitful when aiming for disicplinization- seem to be evident. A double strategy, going for both integration within the disciplines and disciplinization through the establishment of a room of one's own seem necessary to guarantee continuity and development of Gender Studies. And here the level of post-graduate studies seem to have been the most rewarding strategy. But that was before Bologna. A more flexible higher education structure favours the development of Gender Studies. The Bologna agreement regarding BA and MA degrees might here present new possibilities for the institutionalization and disciplinization of the subject. Since European competition and collaboration can be expected to increase this also represents a chance to improve the situation in countries lagging behind regarding the institutionalization and disciplinization of Gender Studies. The Nordic region here has a model to export but also to further develop in the healthy competition between the Nordic countries themselves. 
Bibliography

- Differences(1997) Vol. 9 no. 3

- Feminist Studies (2001) Vol. 27 no. 2

- Griffin, Gabriele (eds) (2002) Women's Employment, Women's Studies and Equal Opportunities 1945-2001.Background data reports of the EU- funded research project " Employment and Women's Studies: The Impact of Women's Studies Training on Women's Employment in Europe" (HPSECT2001-00082), University of Hull

- Griffin, Gabriele, with Medhurst, Pam and Trish Green (2005) Disciplinary Boundaries between the Social Sciences and Humanities: National Report on the UK. www.hull.ac.uk/researchintegration.

- Holm, Ulla and Mia Liinason (2005) Disciplinary Boundaries between the Social Sciences and Humanities: National Report on Sweden. www.hull.ac.uk/researchintegration.

- Jordansson, Birgitta (2005) Jämställdhet och genus på akademins villkor. Två exempel på det vetenskapliga fältets agerande i samband med politiska satsningar, Kvinnovetenskaplig tidskrift, nr 4.

- Keskinen, Suvi and Harriet Silius (2005) Disciplinary Boundaries between the Social Sciences and Humanities: National Report on Finland. www.hull.ac.uk/researchintegration.

- Le Feuvre, Nicky and Milka Metso (2005) Disciplinary Boundaries between the Social Sciences and Humanities: National Report on France. www.hull.ac.uk/researchintegration

- Rosenbeck, Bente (1998) Nordic women's studies and gender research, chapter in Drude von der Fehr, Bente Ronsenbeck\& Anna. G Jónasdóttir(eds) Is there a Nordic feminism? London: UCL Press

- Törnqvist, Maria(2006) Könspolitik på gränsen: Debatterna om Varannan damernas och Thamprofessurerna. Lund: Arkiv förlag

- Widerberg, Karin, Braaten, Eva Sigrid and Ida Hjelde (2005) Disciplinary Boundaries between the Social Sciences and Humanities: National Report on Norway. www.hull.ac.uk/researchintegration.

- Widerberg, Karin (2000) Gender and Society, chapter in Heine Andersen \& Lars Bo Kaspersen (eds) Classical and Modern Social Theory. Oxford: Blackwell

\footnotetext{
${ }^{\mathrm{i}}$ Disciplinization refers to the question whether gender studies and gender research is or ought to be a discipline in its own right. Quite often its institutionlization in the form of journals, studies and research programs and centres are argued as a proof hereof. Although related; insitutionlization affects ways of doing the discipline as well as the other way around, they still give rise to different questions.

ii The terms Women's Studies, Women's Research/Feminist Research and Gender Studies and Gender Research are used interchangeably, trying to transmit the national flavour as well as any change over time within a given national context. When generalizing, the term Women's Studies and Gender Studies will here be used.
} 